\title{
Pengaruh Konsentrasi Pupuk Organik Cair Nasa dan Pemberian Mulsa Organik Terhadap Pertumbuhan dan Hasil Bawang Merah (Allium cepa L.)
}

\author{
Umar Battong, Kun Rawan Sari dan Nasrah
}

STIPER Muhammadiyah Tanah Grogot Kabupaten Paser (Kal-Tim)

Jln. Pangeran Menteri no. 96, Tlp/Hp. 081355382922, Tanah Grogot.

e-mail : battongumar@yahoo.co.id

\begin{abstract}
Penelitian bertujuan untuk mengetahui pertumbuhan dan hasil bawang merah terhadap pemberian POC NASA dan Mulsa Organik serta interaksinya. Penelitian ini dilaksanakan di Desa Long Pinang, Kecamatan Pasir Belengkong, Kabupaten Paser, (Juli 2017 - September 2017). Rancangan percobaan menggunakan Rancangan Acak Kelompok (RAK) dengan dua faktorial dan tiga ulangan. Faktor pertama mengunakan perlakuan pertama tanpa POC NASA, perlakuan kedua POC NASA $10 \mathrm{ml} /$ liter air, perlakuan ketiga POC NASA $15 \mathrm{ml} / \mathrm{liter}$ air. Faktor kedua menggunakan perlakuan pertama tanpa menggunakan mulsa organik, perlakuan kedua menggunakan mulsa alang-alang ketebalan $2 \mathrm{~cm} /$ bedengan, perlakuan ketiga menggunakan mulsa jerami ketebalan $2 \mathrm{~cm} /$ bedengan. Hasil percobaan menujukan terdapat interaksi nyata antara Pupuk Organik Cair NASA dan mulsa organik pada parameter produksi berat basah umbi perpetak dan produksi umbi per hektar terhadap pertumbuhan dan hasil bawang merah. Adapun perlakuan Pupuk Organik Cair NASA berpengaruh tidak nyata terhadap semua parameter yang diamati, mulsa organik berpengaruh nyata terhadap parameter yang diamati yaitu produksi berat basah umbi per petak dan produksi umbi/hektar, sedangkan interaksi berpengaruh tidak nyata terhadap semua parameter yang diamatik
\end{abstract}

Keywords : Konsentrasi pupuk organik; nasa; mulsa organik; bawang merah

\section{Pendahuluan}

Tanaman bawang merah diduga berasal dari Asia Tengah, terutama di sekitaran Palestina dan India. Namun sebagian literatur juga memperkirakan tanaman bawang merah berasal dari Asia Tenggara dan Mediteranea. Menurut Adi Prayitno (2005), tanaman bawang merah merupakan tanaman tertua dari budidaya tanaman lainnya. Hal ini bisa dibuktikan karena bangsa Mesir pada zaman I dan II atau 3200-2700 sebelum masehi, sering melukiskan bawang merah pada patung dan tugu- tugu mereka. Sementara di Israel tanaman bawang merah diperkirakan telah dikenal sejak tahun 1500 sebelum masehi. Sedangkan di Yunani Kuno bawang merah telah dikembangkan sebagai sarana pengobatan sejak tahun 2100 sebelum masehi. Bawang merah memiliki nama latin Allium cepa L.

Produksi bawang merah di Kalimantan Timur pada tahun 2014 sebesar 387,70 ton, mengalami peningkatan sebanyak 342,10 ton (750,22 persen) dibandingkan pada tahun 2013. Peningkatan produksi tersebut disebabkan meningkatnya luas panen sebesar 39,00 hektar atau sebesar 433,33 persen. Sedangkan, persentase produksi bawang merah yang relatif besar tahun 2014 adalah Kabupaten Kutai Kartanegara (57,96 persen), Paser (26,93 persen) dan Berau (14,95 persen), sedangkan 4 kabupaten/kota yaitu Kutai Barat, Balikpapan, Samarinda dan Bontang tidak ada produksi bawang merah. Produksi dan luas panen tertinggi dicapai pada tahun 2014, dimana produksi mencapai 387,70 ton dan luas panen mencapai 48,00 hektar. Sementara produktivitas tertinggi sebesar 8,08 ton per hektar, dan kabupaten yang mempunyai produktivitas tertinggi adalah Kutai Kartanegara sebesar 13,22 ton per hektar dicapai pada tahun 2014 (BPS KALTIM, 2015).
Pengembangan budidaya bawang merah di Kabupaten Paser sudah dimulai sejak sekitar tahun 1998. Bawang merah pada awalnya dibudidayakan di Muara Komam Kabupaten Paser. Pemerintah daerah melihat ada peluang besar untuk tanaman bawang merah meskipun masih jarang ditemukan di Paser, maka pemerintah daerah setempat pun telah menyiapkan lokasi untuk budidaya tanaman bawang di tiga kecamatan yakni Kecamatan Kuaro, Muara Komam dan Batu Engau. Masing-masing kecamatan terdapat satu wilayah desa yang dijadikan daerah sentra budidaya. Tiga desa yang sudah dijadikan tempat budidaya adalah Desa Padang Jaya, Desa Sekuan Makmur dan Desa Tampakan.

POC NASA adalah Pupuk Organik Cair produksi PT Natural Nusantara (NASA). Formula ini dirancang secara khusus terutama untuk mencukupi kebutuhan nutrisi lengkap pada tanaman juga peternakan dan perikanan yang dibuat murni dari bahan-bahan organik dengan fungsi multiguna.

Kandungan POC NASA, N $0.12 \%$, P2O5 $0.03 \%$, K $0.31 \%$, Ca 60.40 ppm, S 0.12\%, Mg 16.88 ppm, Cl 0.29 \%, Mn 2.46 ppm, Fe 12.89 ppm, Cu < 0.03 ppm, Zn 4.71 ppm, Na $0.15 \%$, B 60.84 ppm, Si $0.01 \%$, Co < 0.05 ppm, Al 6.38 ppm, $\mathrm{NaCl} 0.98 \%$, Se $0.11 \mathrm{ppm}$, As $0.11 \mathrm{ppm}, \mathrm{Cr}$ $<0.06$ ppm, Mo < 0.2 ppm, V < 0.04 ppm, SO4 $0.35 \%$, $\mathrm{C} / \mathrm{N}$ ratio $0.86 \%$, ph 7.5 , Lemak $0.44 \%$, Protein $0.72 \%$ sedangkan kandungan lain, Asam-asam organik (Humat $0,01 \%$, Vulvat, dll), sebagai Zat perangsang tumbuh, Auksin, Giberelin, Sitokinin (Indrakusuma, 2000).

Mulsa ialah bahan yang ditebarkan di atas permukaan tanah dengan tujuan untuk melindungi tanah dan akar tanaman dari pengaruh pukulan air hujan, retakan, penguapan/evaporasi, menekan pertumbuhan gulma, dan untuk mempertahankan produktivitas tanah. Bahan yang umum digunakan sebagai mulsa adalah plastik lembaran 
atau menggunakan sisa hasil tanaman (organik) berupa jerami, batang tanaman, serbuk gergaji, dll. Menggunakan mulsa organik pada permukaan lahan bisa menghambat hilangnya air tanah dari dalam tanah (Yunindanova, 2010).

Pemberian mulsa secara umum memperbaiki kelembaban tanah, yang disebabkan oleh berkurangnya air oleh aliran permukaan dan evaporasi. Mulsa juga mempengaruhi kelembaban tanah secara tidak langsung, yaitu dengan mengurangi erosi. Tanah yang mengalami erosi berat mempunyai kapasitas menahan air rendah, sehingga tanahnya juga mempunyai kandungan bahan organik yang rendah. Apabila diberikan mulsa akan mempengaruhi kondisi tanah secara tidak langsung berupa meningkatnya jumlah dan aktivitas mikoorganisme tanah, sehingga berdampak pada pengaruh struktur tanah yang menjadi lebih baik (Yunindanova, 2010).

\section{Metodologi}

Penelitian dilaksanakan pada bulan Juli 2017 sampai bulan September 2017 dan lokasi penelitian dilaksanakan di Desa Olong Pinang, Kecamatan Paser Belengkong, Kabupaten Paser. Bahan yang digunakan dalam penelitian ini adalah bibit bawang merah varietas Bima Brebes label biru turunan ke empat (berasal dari Desa. Bersole, Kecamatan, Adiwerna,Tegal, dan mempunyai masa simpan $\pm 3-4$ bulan) kapur dolomit, pupuk organik cair POC NASA, jerami padi, alang-alang, pupuk NPK Phonska, pupuk kandang, pestisida (fungisida), pupuk KCL dan ZPT Gibro. Alat yang digunakan dalam penelitian ini adalah cangkul, parang, pisau, palu, paku, gergaji, penggaris/meteran, ember, kayu, gembor, hand sprayer, pompa air, timbangan analog, timbangan digital, alat tulis, label nama dan kamera.

Rancangan yang digunakan dalam penelitian ini adalah Rancangan Acak Kelompok (RAK). Yang disusun dalam faktorial dengan 2 faktor. Faktor pertama adalah Konsentrasi POC NASA (N) terdiri dari 3 taraf yaitu : n1 = Tanpa POC NASA, n2 = POC Nasa10 ml/liter air n3= POC Nasa $15 \mathrm{ml} /$ liter air. Faktor yang kedua adalah pemberian Mulsa Organik (M) terdiri dari 3 taraf yaitu $\mathrm{m} 1$ = tanpa menggunakan mulsa, $\mathrm{m} 2=$ mulsa alang-alang ketebalan $2 \mathrm{~cm} /$ bedengan, $\mathrm{m} 3=$ mulsa jerami ketebalan $2 \mathrm{~cm} /$ bedengan. Terdapat 3 perlakuan terdiri dari 9 kombinasi yang diulang sebanyak 3 kali. Setiap kombinasi perlakuan terdiri dari 4 tanaman sampel, sehingga jumlah populasi pada setiap ulangan adalah $9 \times 4=36$ tanaman sampel, sedangkan jumlah populasi dari semua ulangan adalah $36 \times 3=108$ tanaman

Analisa Data dilakukan untuk mengetahui pengaruh konsentrasi POC NASA dan pemberian mulsa organik terhadap pertumbuhan tanaman bawang merah, maka data yang diperoleh dianalisis dengan analisa sidik ragam. Apabila sidik ragam berpengaruh tidak nyata ( $\mathrm{F}$ hitung perlakuan < F tabel 0,05) tidak dilakukan uji lanjut, jika sidik ragam berpengaruh nyata $(\mathrm{F}$ hitung perlakuan $>\mathrm{F}$ table 0,05) maka dilanjutkan dengan uji lanjut berbeda nyata $(\mathrm{BNT})$ pada taraf $5 \%$.

\section{Hasil}

Hasil analisa sidik ragam menunjukkan bahwa perlakuan Konsentrasi Pupuk Organik Cair NASA (N), Mulsa Organik (M) dan Interaksinya (N $\quad \mathrm{X} \quad \mathrm{M})$ berpengaruh tidak nyata terhadap tinggi tanaman bawang merah. Namun ada kecenderungan perlakuan $\mathrm{n} 2 \mathrm{~m} 3$, memberikan tinggi tanaman yang lebih tinggi $(33,67 \mathrm{~cm})$, sedangkan perlakuan $\mathrm{n} 1 \mathrm{~m} 1$ menunjukkan tinggi tanaman yang lebih pendek $(23,67 \mathrm{~cm})$.

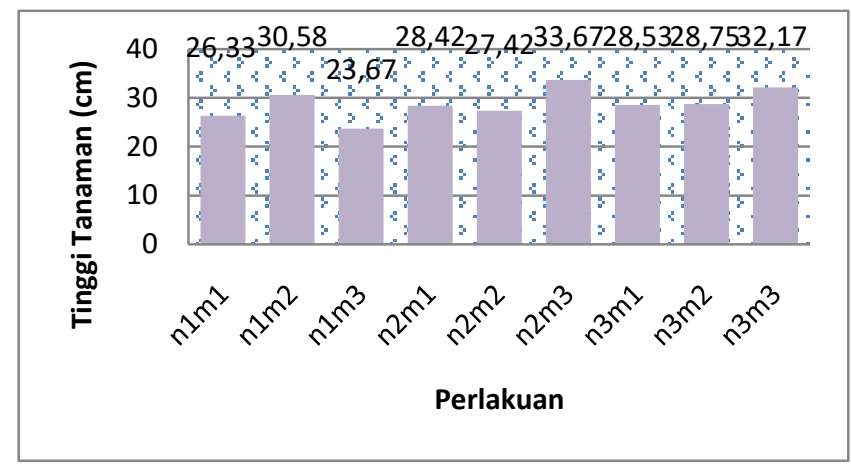

Gambar 1: Diagram batang rata-rata tinggi tanaman umur $4 \operatorname{MST}(\mathrm{cm})$.

Hasil analisa sidik ragam menunjukkan bahwa perlakuan Konsentrasi Pupuk Organik Cair NASA (N), Mulsa Organik (M) dan Interaksinya (N $\quad X \quad M)$ berpengaruh tidak nyata terhadap rata-rata jumlah daun. Diagram rata-rata jumlah daun dapat dilihat pada (Diagram gambar 6), namun ada kecenderungan perlakuan $\mathrm{n} 1 \mathrm{~m} 3$, memberikan jumlah daun yang lebih banyak $(11,75$ helai), sedangkan perlakuan $\mathrm{n} 1 \mathrm{~m} 2$ menunjukkan jumlah daun yang lebih sedikit (10,25 helai).

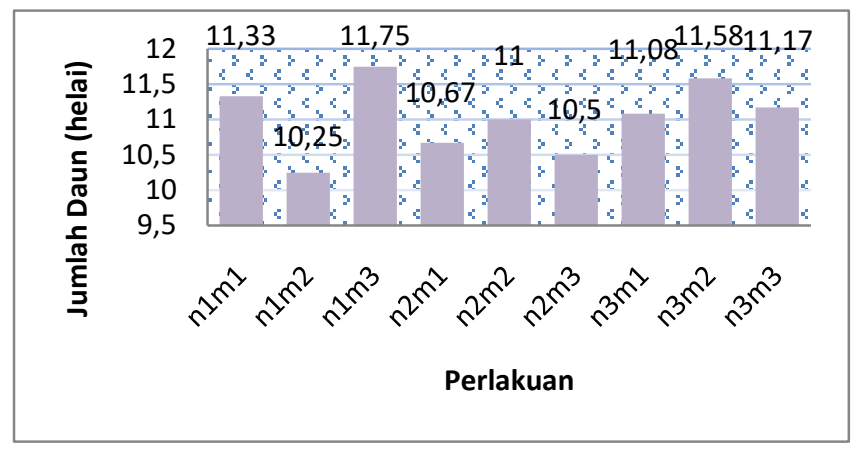

Gambar 2: Diagram batang Rata-rata jumlah daun umur 4 MST.

Hasil analisa sidik ragam menunjukkan bahwa perlakuan Dosis Pupuk Organik Cair NASA (N), Mulsa Organik (M) dan Interaksinya (N X M) berpengaruh tidak nyata terhadap rata-rata jumlah umbi perrumpun (sampel) akhir pengamatan. Diagram rata-rata jumlah umbi dapat dilihat pada (Diagram gambar 7), namun ada kecenderungan perlakuan n1m3, memberikan jumlah umbi 
yang lebih banyak $(7,58)$, sedangkan perlakuan $\mathrm{n} 1 \mathrm{~m} 2$ menunjukkan jumlah umbi yang lebih sedikit $(5,67)$.

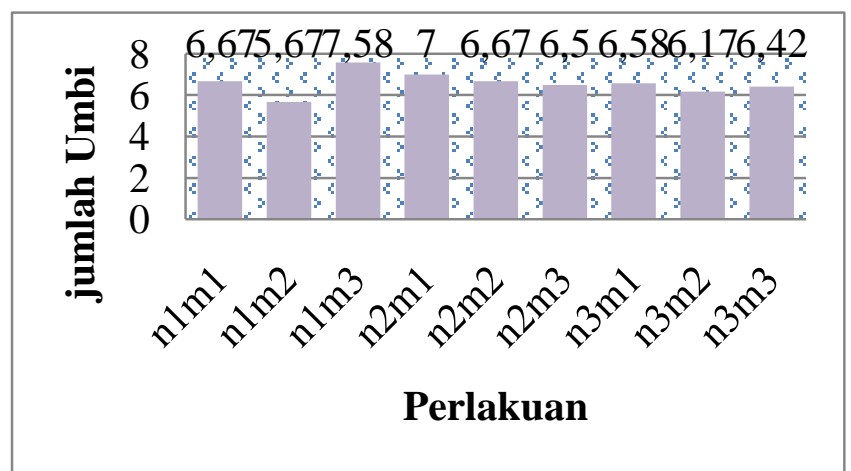

Gambar 3: Diagram Batang Rata-rata Jumlah Umbi Perrumpun

Hasil analisa sidik ragam menunjukkan bahwa perlakuan Konsentrasi Pupuk Organik Cair NASA (N), Mulsa Organik (M) dan Interaksinya (N $\mathrm{X} \quad \mathrm{M}$ ) berpengaruh tidak nyata terhadap rata-rata berat umbi perrumpun (sampel) akhir pengamatan. Namun ada kecenderungan perlakuan $\mathrm{n} 1 \mathrm{~m} 3$, memberikan jumlah umbi yang lebih banyak $(35,67 \mathrm{gr})$, sedangkan perlakuan n1m2 menunjukkan jumlah umbi yang lebih sedikit (28,58 gr).

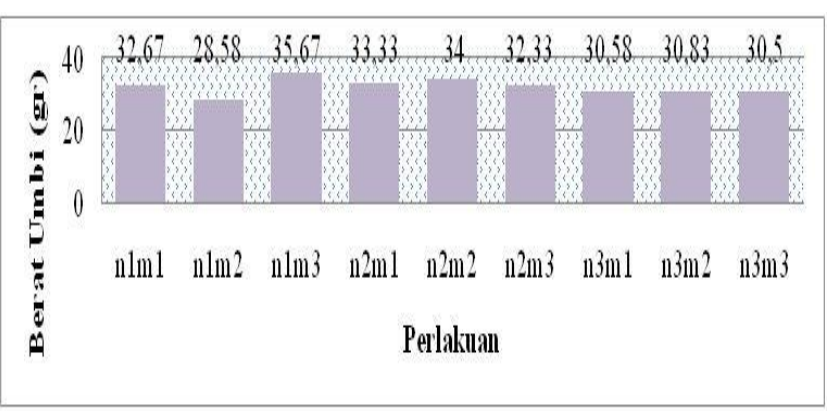

Gambar 4 : Diagram Batang Rata-rata Berat Umbi Perrumpun (gr).

Hasil analisa sidik ragam menunjukkan bahwa perlakuan Konsentrasi Pupuk Organik Cair NASA (N) dan Mulsa Organik (M) berpengaruh nyata terhadap produksi berat basah umbi perpetak, sedangkan interaksinya (N X M) tidak berpengaruh nyata terhadap produksi berat basah umbi perpetak. Hasil uji BNT 0,05 dapat dilihat pada tabel 1 .

Tabel 1.Rata-rata Berat Umbi Perbedengan (kg) Akhir Perlakuan pada Perlakuan Konsentrasi Pupuk Organik Cair NASA dan Mulsa Organik

\section{Mulsa organik}

Rata-rata

\begin{tabular}{ccccc} 
& $\mathbf{m 1}$ & $\mathbf{m} 2$ & $\mathbf{m 3}$ & \\
\hline $\mathbf{n 1}$ & 1,07 & 0,87 & 0,87 & $\mathbf{1 , 1 5}$ \\
$\mathbf{n 2}$ & 0,89 & 0,91 & 0,85 & $\mathbf{0 , 8 8}$ \\
n3 & 1,02 & 0,86 & 0,84 & $\mathbf{0 , 9 1}$ \\
\hline Rata-rata & $\mathbf{0 , 9 9}^{\mathbf{a}}$ & $\mathbf{0 , 8 5}^{\mathbf{a}}$ & $\mathbf{0 , 8 5}^{\mathbf{b}}$ &
\end{tabular}

* Angka rata-rata yang diikuti huruf yang tidak sama menunjukkan berbeda nyata berdasarkan uji BNT 0,05 $(\mathrm{BNT}=0,11)$.

Berdasarkan uji BNT 0,01 menunjukkan perlakuan Tanpa Menggunakan Mulsa (m1), memiliki rata-rata berat umbi yang lebih tinggi $(0,99 \mathrm{~kg})$ dan berbeda nyata dari perlakuan $\mathrm{m} 3$ namun tidak berbeda nyata dengan perlakuan $\mathrm{m} 2$.

\begin{tabular}{crrrr}
\hline \multirow{2}{*}{ POC NASA } & \multicolumn{3}{c}{ Mulsa organik } & Rata-rata \\
\cline { 2 - 4 } & $\mathbf{m 1}$ & $\mathbf{m 2}$ & $\mathbf{m 3}$ & \\
\hline $\mathbf{n 1}$ & 5,33 & 4,33 & 4,33 & 4,66 \\
$\mathbf{n 2}$ & 4,45 & 4,53 & 4,23 & 4,40 \\
$\mathbf{n 3}$ & 5,12 & 4,29 & 4,20 & 4,54 \\
\hline
\end{tabular}

Rata-rata $\quad 4,97^{\mathrm{a}} \quad 4,38^{\mathrm{a}} \quad 4,25^{\mathrm{b}}$

* Angka rata-rata yang diikuti huruf yang tidak sama menunjukkan berbeda nyata berdasarkan uji BNT 0,05 $(\mathrm{BNT}=0,59)$.

Berdasarkan uji BNT 0.05 menunjukkan perlakuan tanpa menggunakan Mulsa Organik (m1), memiliki ratarata berat umbi yang lebih tinggi (4,97 ton) dan berbeda nyata dari perlakuan $\mathrm{m} 3$ namun tidak berbeda nyata dengan perlakuan $\mathrm{m} 2$.

Hasil penelitian menunjukkan bahwa pertumbuhan dan hasil bawang merah terbaik di peroleh pada perlakuan tanpa menggunakan Pupuk Organik Cair NASA (n1). Hal ini di duga karena tanaman bawang merah melangsungkan pertumbuhan yang baik dan memperoleh hasil yang optimal. Menurut Kartono (2005) pertumbuhan terjadi karena proses-proses pembelahan sel dan perpanjangan sel, dimana proses-proses tersebut memerlukan banyak unsur hara. MacNab, ect (1983) menambahkan bahwa pertumbuhan dan hasil suatu tanaman dipengaruhi oleh keadaan lingkungan tumbuhnya.salah satu faktor lingkungan yang penting adalah ketersediaan unsur hara dan pengendalian organisme pengganggu tanaman. Lansida (2009) menyatakan bahwa pemberian unsur hara makro dan mikro dalam jumlah yang cukup dan seimbang, mampu meningkatkan nutrisi yang diperlukan tanaman, dan digunakan sebagai sumber energi bagi tanaman. Selain itu untuk mendapatkan pertumbuhan dan hasil yang optimal, pupuk yang diberikan harus dengan konsentrasi atau dosis yang tepat.

Samsudin (2000) menyatakan bahwa pemberian pupuk organik cair harus memperhatikan konsentrasi yang diaplikasikan pada tanaman. Lingga dan Marsono (2000) menambahkan bahwa konsentrasi merupakan faktor yang sangat vital dan memiliki pengaruh yang besar terhadap keberhasilan pemupukan terutama pemupukan melalui daun. Solusi untuk mengatasi Ketergantungan terhadap penggunaan pupuk anorganik yaitu dengan memberikan pupuk organik. Pupuk organik mempunyai manfaat untuk 
meningkatkan produktivitas lahan pertanian, sebab pupuk organik dapat meningkatkan kandungan unsur hara organik didalam tanah yang tadinya rusak oleh penggunaan pupuk kimia menjadi lebih subur (Pasaribu, 2011). Selain itu, pupuk organik mempunyai peranan penting dalam mempertahankan kesuburan fisik, kimia, dan biologi tanah. Tanah yang kaya bahan organik bersifat lebih terbuka sehingga aerasi tanah lebih baik dan tidak mudah mengalami pemadatan dibandingkan dengan tanah yang mengandung bahan organik rendah (Sutanto, 2002).

\section{Kesimpulan}

Berdasarkan hasil dan pembahasan penelitian ini dapat disimpulkan sebagai berikut :

1. Perlakuan konsentrasi Pupuk Organik Cair NASA berpengaruh tidak nyata terhadap semua parameter yang diamati.

2. Perlakuan mulsa organik berpengaruh nyata terhadap produksi berat basah umbi per petak/sampel dan produksi umbi/hektar pada tanaman bawang merah dapat dilihat pada parameter produksi berat basah umbi per petak/sampel dan produksi umbi per hektar.

3. Perlakuan interaksi Konsentrasi Pupuk Organik Cair NASA (N) dan mulsa organik (M) berpengaruh tidak nyata terhadap semua parameter yang diamati.

\section{Daftar Pustaka}

Adi Prayitno. 2015. Respon Pemberian Kapur Dolomit dan Pupuk Organik Granule Moderen Terhadap Pertumbuhan dan Hasil Bawang Merah(Allium ascalonicum L.) pada Tanah Berpasir. Palangkaraya: Universitas Muhammadiyah Palangkaraya Fakultas Pertanian Dan Kehutanan Muhamadiyah Palangkaraya.

Badan Pusat Statistik. 2015. Kalimantan Timur dalam angka 2015. Samarinda.

Indrakusuma, 2000. Proposal Pupuk Organik Cair Supra Alam Lestari. PT. Supra Pratama Alam. Yogyakarta.

Kartono, D. 2005. Tanggapan Pertumbuhan dan Hasil Kedelai Hitam Terhadap Penggunaan Pupuk Organik dan Biopestisida Gulma Siam (chromolaena ordorata). Dalam jurnal (Nahda Fahmi,Syamsudin, dan Ainun Marliah) Pengaruh Pupuk Organik dan Anorganik Terhadap pertumbuhan dan Hasil Kedelai (Glycine $\max ($ L.)Merril).

Lansida.2009. Bawang Merah (Allium cepa L.) http://lansida.blogspot.com/2009/09/bawangmerah-allium-cepa-1.html (Diakses pada sabtu, 17 Juli 2016).

Lingga, P. dan Marsono. 2000. Petunjuk Penggunaan Pupuk. Jakarta : Penebar Swadaya.
MacNab, A.A., A.F. Sherf and J.K. Springer. 1983. Identifying Diseases of Vegetables. The Pennsylvania State University. College of Agriculture, University park, Pennsylvania.62.pp.

Pasaribu, M, S., Wan Arfiani Barus dan Heri Kurnianto.2011. Pengaruh Konsentrasi Dan Interval Waktu Pemberian Pupuk Organik Cair (Poc) Nasa Terhadap Pertumbuhan Dan Produksi Jagung Manis (Zea mays saccharata Sturt). Program Studi Agroekoteknologi Fakultas Pertanian Universitas Muhammadiyah Sumatera Utara.

Samsudin. 2000 . Bawang Merah . Bima Cipta, Bandung.75 hlm.https: //jurnalfloratek.wordpress.com/tag/bawang merah/. Diakses pada tanggal 8 Juni 2016.

Sutanto.R, 2002. Penerapan Pertanian Organik. Permasyarakatan dan Pengembangannya. Penerbit Kanisius. Yogyakarta.

Yunindanova, Mercy Bientri; Agusta, Herdhata; Asmono, Dwi (2010). "Tingkat Kematangan Kompos Tandan Kosong Sawit dan Penggunaan Berbagai Mulsa Terhadap Pertumbuhan dan Produksi Tanaman Tomat (Lycopersicon esculentum Mill.) dan Cabai (Capsicum annuum L.)". Agronomy and Horticulture IPB. 